\title{
A relationship perspective on organisational culture and good governance in sport
}

\author{
Vassil Girginov
}

\section{Introduction}

Despite over 50 years of research, the concepts of organisational culture and good governance have not lost their currency and continue to intrigue researchers and practitioners. A search on 'organisational culture' in the Web of Science data base returned 19,096 articles including 1,501 published in 2020 alone. The search for 'good governance' showed 18,397 articles of which 2,035 were published in 2020.

It is generally accepted that governance is concerned with steering collective actions towards achieving certain results. Injecting the adjective 'good' in front of governance serves as a qualifier of whether it is effective or not and implies value judgement which takes the discussion into the realms of culture and ethics. Sport organisations come in different shapes and sizes and what tells them apart is the specific culture they subscribe to.

Extant literature on sport governance focuses mostly on improving organisational structure and practices but culture-informed analyses of governance are almost absent or peripheral at best: Numerato (2010) addresses how different sport governance cultures promote social capital; Li, MacIntosh and Bravo (2012) focus on the intercultural management in sport organisations; Sotiriadou and De Haan (2019) explore the role of gender equity strategies in creating a gender equitable governance culture; and Geeraert (2018) suggests that culture could be an obstacle to good governance. Shilbury, Ferkins and Smythe's (2013) study shows the emergence of commercialisation culture in sport organisations as a major contributing factor for the acceptance of corporate governance codes in sport. It is also worth mentioning that the authoritative governance audit carried out by the Association of International Summer Olympic Federations does not even include organisational culture as an indicator despite the explicitly stated aim "to promote a better culture of governance" (ASOIF 2017, p. 3).

What most studies tend to overlook is that the implementation of any conception of good governance inevitably requires, in the first place, a change in the value system that underpins the culture of the organisation. For this change to take place it ought to address the deeply rooted values and believes of the members of the organisation so they can internalise the principles of good governance 
and enact them in their daily routines. This chapter interrogates the relationship between good governance and organisational culture. It argues that both good governance and organisational culture are mutually constructive normative concepts which promote a particular view of what ought to be regarded as public good. However, this tends to be an unequal relationship because the current belief in the power of good governance to enhance the effectiveness of sport has become an ideology promoting isomorphism through a universal model of organisational culture imposed by governmental and other agencies nationally and internationally.

The chapter proceeds as follows: the first and second sections interrogate the concepts of organisational culture and good governance, respectively. Section three examines the constructive relationship between the two concepts, followed by a review of culture of codification of governance and its framing as synonymous with effectiveness, and finally some reflections and implications for research and practice are discussed.

\section{Culture and organisational culture}

Decades of research have not resulted in establishing an agreement on the definition of organisational culture and good governance and conceptual approaches continue to proliferate. In 1952, one of earlier anthropologists, Kroeber and Kluckhohn's critical review of concepts and definitions of culture produced a list of 164 different definitions. More recently, Jung et al. (2009) identified 48 validated instruments for measuring organisational culture.

Most research on culture explicitly acknowledges the linguistic challenges in defining this concept. Williams (1989) famously opined that culture is one of the two or three most complicated words in the English language. He also elucidated that "a culture has two aspects: the known meanings and directions, which its members are trained to; the new observations and meanings, which are offered and tested" (p. 6). This is an important observation as it allows to distinguish between two main approaches to organisational culture. The first is its conceptualisation as something organisations have also referred to as the objectivist-functionalist view. According to Alvesson (2002), this perspective usually conceives culture as an organisational attribute, which can be operationalised and studied empirically. This turns culture into a variable and the main concern then becomes to understand its relationship with organisational outcomes such as effectiveness, performance, and productivity.

The second perspective (symbolic interactionism) sees organisations as cultures. It corresponds to William's interpretation of culture as the creation and testing of meaning by organisational members and the processes that facilitate the understanding of this meaning and its enactment. From this perspective, organisational culture is not a variable but a root metaphor (cf. Smircich 1983). Morgan (1997) has developed eight root metaphors to describe organisations including one of organisations as cultures. According to this metaphor, organisations can 
be viewed as mini societies grounded in their own ideologies, beliefs, and values. Members of organisations then are engaged in a constant construction process of shared systems of meaning that are accepted, internalised, and acted upon at every level of an organisation and that allow them to understand events, actions and situations in a distinctive way. Morgan (1997) refers to this process as the enactment of culture. This interpretation of organisations as culture is much more difficult to quantify and study empirically.

A related interpretation is Feldman's (1986) culture-as-context approach to management, which stresses the role of symbolic forms including concepts, theories, plans and goals in determining what is changing in organisations. Those forms, together with sport organisations' structures, rules, policies, and symbols perform an interpretative function, because they act as primary points of reference for the way people think about, and make sense of, the context in which they work. Thus, sport managers' key role is that of the management of meaning.

An important contribution to the objectivist-functionalist view of organisational culture is Martin's (1992) three perspectives on organisations. Martin argues that organisations do not have homogeneous cultures rather there are always three perspectives present in an organisation. These perspectives are reflective of the hierarchical structure of organisations and include integration, differentiation and fragmentation that correspond to the top management of the organisation, the middle/departmental level, and the front-line staff level, respectively.

Maitland, Hills and Rhind's (2015) systematic review of organisational culture in sport utilised Martin's perspectives and identified 33 studies published between 1995 and 2013. The authors made three important observations including that: (i) some $75 \%$ of the studies came from North America and Australia; (ii) $70 \%$ of studies employed the integration perspective (i.e. culture is consistent across the environment), (iii) in contrast to wider organisational culture literature, research in sport tends to assume that culture was a variable to manipulate in an organisation.

\section{A cultural perspective on good governance}

Like culture, the concept of governance (from Greek 'kybernetes' which means steersman) is equally hard to define. For a start, governance does not translate in many languages, which raises the question of how it is possible to define a concept when there is no word for it. Offe (2009) even asks whether governance was an empty signifier. While the roots of governance can be traced back to the first forms of human existence, its codification in the form of 'good governance' is a relatively new phenomenon. Aguilera and Cuervo-Cazurra's (2009) examination of 196 distinct codes of good governance issued by 64 countries notes that the first country code of good governance was issued in 1978 in the United States, followed by Hong Kong in 1989, Ireland in 1991 and the UK in 1992. The first global code of good governance in sport was adopted by the International 
Olympic Committee (IOC) congress in 2009 and was modelled on the practices of the corporate sector.

Nonetheless, commentators generally agree that the concept is concerned with the steering of collective action. It is also widely accepted that governance is a Western, and an Anglo-Saxon product (Hofstede 1993). This acknowledgement points out to the cultural origins of the concept to which we return later in the analysis. While a cultural perspective on governance is important, it is not enough to appreciate its complexity. Căjvăneanu (2011, p. 73) offers an extensive review of the emergence of the concept of governance. She elucidates that: "The rise of the concept of governance has been largely stimulated by the increased political, economic and social diversity. Throughout the 1904's, -1990s' it has explicitly recognised two interrelated failure of the state and the market to address complex social issues. But the diversity of interests and needs is also reflective of an ever-increasing cultural diversity rooted in different values and world ontologies. Both in the European and the world context, governance has emerged mainly as an economic concern (i.e. economic conditionality)".

Thus, like culture, governance is a social construct and at its core, governance is a political theory concerned with the relationship between the state and society (Treib et al. 2007). This relationship has been marked by the simultaneous failure of the state and the market to deliver public value, so there was a need for an alternative approach that would recognise the limits of traditional government and the market to deal with uncertainties. What emerged, according to Rhodes (1996, pp. 652-653), is "a change in the meaning of government, referring to a new process of governing; or changed condition of ordered rule; or a new method by which society is governed". Rhodes' definition of governance illustrates the political interpretation of the concept, which is one of its two main meanings. The second main meaning of governance is the administrative one concerned with "the setting of rules, the application of rules, and the enforcement of rules" (Kjær 2004, p. 10).

Conceptualisations of governance in sport have drawn from both interpretations as demonstrated by Jean Camy, pointed out to the ontological and deeply rooted cultural foundations of the concept: "When thinking about Good Governance we shall not focus too heavily on procedures. Good Governance has most and foremost to deal with a way of being, organizing and thinking!" (Camy, cited in ISCA 2013, p. 9).

Hofstede (1993) highlights the significance of culture to management theory and practices by simply noting that "management theories are human" (p. 82). He develops a model for analysing and measuring culture and applied it to examine management in different cultural settings. Hofstede points out to three idiosyncrasies typical for US management theories that are not shared by the rest of the world including a stress on market processes, and on individual, and a focus on managers rather than on workers.

What follows from the Hofstede is that we ought to concede the possibility that the notion of good governance can be underpinned by different ontologies. 
Khan (2012) highlights one such alternative ontology by distinguishing between the dominant liberal 'market-enhancing' approach to governance, and 'growthenhancing' governance appropriate for developing countries which draws on the historical evidence of catching up. Khan concludes "good governance as it has been defined cannot plausibly be a precondition for development" (p. 52). Khan's point applies not only to 'developing countries' but equally to developed ones as it highlights the importance of organisational capabilities as well as the dominant resource distribution policies as a precondition for sport development in any country.

Ultimately, the dominant neoliberal conception of good governance is concerned with greater organisational effectiveness. This view is echoed by most national and major international organisations including the IOC, as illustrated by the European Union's expert group on good governance (2013). In addition to recognising good governance both as a framework and a culture, the expert group also explicates that "... it is important to underline that good governance essentially comprises a set of standards and operational practices leading to the effective regulation of sport" (p. 5). This interpretation of governance sees it as a means to an end, where good governance is positively correlated with greater effectiveness of sport organisations, and thus mirrors the model promoted by the corporate sector. Spencer-Oatey (2012) offers a useful summary of 12 main characteristics of culture, which complement the two approaches to organisational culture outlined above by highlighting its main properties. These characteristics are juxtaposed with good governance in the next section.

\section{Organisational culture and good governance as social constructs}

Scholars have interrogated the link between good governance and organisational culture and there is a limited research addressing this issue in sport as well. The two concepts of culture and governance exemplify Morgan's (1997) metaphors of organisations as culture and political system, respectively. As he has noted, culture has a tacit political dimension, which does not allow grasping the real importance of culture through the culture. This is because the metaphor of organisations as political system draws attention to a myriad of patterns of competing personal and group interests, power struggles, conflict resolution, individual and institutional censorship, and leadership inherent in any organisational setting.

Culture and governance permeate the five basic social institutions guiding human existence including the family, government, economy, education, and religion. Regardless of the culture in which social institutions are nested, as Koskinen (2014) observes, their core function is consistent and is concerned with determining and regulating membership and ownership, legitimising power, and controlling and socialising young generation. That is, they exist to govern.

Culture and governance share another important similarity. Both represent nomos-building activities as they seek to reduce uncertainty and to confer order 
(Girginov et al. 2006). Thus, interpretations of governance are cultural constructs underpinned by core assumptions and values held by members of professional communities in different countries. The evolution of modern sport from a pass time of the privileged few to a politically and economically sanctioned activity for the masses supports this conclusion (Horne, Thomlinson \& Whannel 1999). Its role in the development of societies has been recognised at the highest political level including the 2007 Lisbon Treaty of the European Union and the UN Millennium Sustainable Goals (United Nations, 2016). Evidently, sport has been democratised as it has become more widely accessible to different groups in society. As a result, its systems of governance have also evolved to accommodate the increasing diversity of participants and practices as well as to ensure its contribution to society. Thus, both culture and governance have been constructed through an ongoing strive for external adaptation and internal integration. This is also what makes them normative concepts as they are concerned with regulating and controlling organisational and human behaviours.

The evolution of the UK code of good governance in sport provides an illustrative case. The first major impetus in its development was ideological and political and came in the late 1990s when the newly elected labour government of Tony Blair introduced the modernisation agenda of society. It entails that sport organisations who receive public funding must improve their effectiveness, so they become a fit partner to the government in delivering its wider social and economic agenda (Houlihan \& Groeneveld 2010). National Governing Bodies of sport (NGB) were also expected to become more fiscally responsible, transparent, democratic, and professional. The conceptual underpinning of modernisation was provided by the tenets of New Public Management with its insistence on strategy, key performance indicators and effectiveness (Houlihan \& Green 2009; Lusted \& O'Gorman 2010). Several successive measures have marked the roll out of good governance across the UK sport sector including the launch in 2004 of the first code by UK Sport, a national strategy towards a better governance in sport in 2012, and the latest Code for Sport Governance in 2016. Walters and Tacon's (2018) examination of the codification of governance in the UK sport sector concludes that the initial adoption of the code was done to create external legitimacy for the organisation, which was then used for its internal legitimacy and to reinforce members' perceptions that the Board was providing sound steering. The authors also make another important point that members perceived the codes as often constraining the autonomy of the Board.

In sum, following Spencer-Oatey's (2012) 12 main characteristics of culture, several points of converge with governance can be identified. First, culture and governance are manifested at different layers of depth including national, organisational, and group for culture, and global, national, and organisational principles for governance. Second, both culture and governance affect behaviour and interpretations of behaviour. Third, culture and governance are associated with social groups such as organisations or teams. Forth, both concepts have universal (etic, i.e. global sport culture and governance principles) and distinctive (emic, 
i.e. sport-specific culture and Board governance practices) elements. Fifth, culture and governance are learned through a process of socialisation and represent social constructs. Finally, culture and governance are subject to gradual change.

\section{A culture of codification of good governance}

There has been a proliferation of good governance codes (GGC) in all sectors of society. For example, the website of the European Corporate Governance Institute (ECGI) provides an extensive list of GGC topped by the UK with 53 codes. Earlier, Aguilera and Cuervo-Cazurra (2009) reported that in 2008, UK and USA had both 25 GGC each compared with an average of 1.5 codes per country for the rest of the world. The correlation between national culture, as represented by the country issuing the GGC, and the number of those codes, is an important one as it points out to the presence of a relationship between the dominant culture of a country and the extent to which it embraces the spirit and practices of GGC.

Haxhi and Van Ees (2010) have tried to explain diversity in the worldwide diffusion of GGC using a sample of 67 countries. The authors conclude that "the dimensions of culture that reflect norms and beliefs in society about the integration of individuals into groups, the equality and the distribution of power, and the tolerance for uncertainty and ambiguity, correlate with the issuance of codes and the identity of the issuing organizations. We find that individualist cultures have a stronger tendency to develop codes" (p. 722). In answering the question "how and why sport issues turn into politics?' Seippel et al. (2018) conclude that regardless of national cultural specifics, "(...) the culture framing of sport issues could be decisive in how they might develop as political issues. We see, more specifically, how our sport cases live and develop differently within various cultures" (p. 680).

Cuervo-Cazurra and Aguilera's (2004) pioneering study of 72 codes in 49 countries offers two main theoretical explanations for the diffusion of GGC including efficiency and legitimation. The two theoretical explanations are closely connected with the essence of governance as positively correlated with effectiveness and efficiency for the former, and organisational culture, being shaped by the strive for external adaptation and internal integration, as expressed through legitimacy, for the latter.

\section{A cultural belief: Good governance equates greater effectiveness}

The diffusion of the GGC across different cultures has largely been driven by a belief that good governance leads to a greater organisational effectiveness and performance. Girginov (2019) questions this assumption and points out to two issues concerning what is understood by effectiveness and how we measure it.

Thus, any discussion on effectiveness ought to account for an organisation's culture and its governance structure and practices. Several large-scale studies 
have explored the link between organisational culture and effectiveness. One of the most comprehensive attempts to interrogate this link is the theory of organisational culture and effectiveness developed by Dennison and Mishra (1995). The authors propose a model based on four organisational culture traits including involvement, consistency, adaptability, and mission. They submit that the "culture may indeed have an impact on effectiveness. Each of the four cultural traits showed significant positive association with a wide range of both subjective and objective measures of organisational effectiveness, as well as interpretable linkages between specific traits and specific criteria of effectiveness" (p. 28). Dennison and Mishra also note the role of organisational size where culture and effectiveness are more closely linked in larger firms due to the coordinating effect of culture in complex systems.

A 47-nation study by Smith, Peterson, and Schwartz (2002) on the role of cultural values as sources of guidance and their relevance to managerial behaviour provides strong evidence that values do predict reliance on those sources of guidance.

Cuervo-Cazurra and Aguilera's (2004) and Haxhi and Van Ees' (2010) studies reveal that the issuers of codes fall in three groups including coercive; normative and mimetic promoted by stock exchange and investors' groups, government and professional associations, and managers' associations respectively. These conclusions tend to suggest that national and corporate cultures exert significant influence on governance practices and that the wider diffusion of GGC tend to promote greater convergence.

However, as the analysis in previous section has illustrated, what really matters is which characteristics and traits of culture are associated with the principles of good governance and how they interpret them. The dichotomy between organisational culture and governance is elucidated by Niedlich et al. (2019) where organisational culture becomes the framework within which good governance takes place. This is because all reasoned action is based on a logic of appropriateness or an understanding of what is true, reasonable, natural, right, and good. At the same time, as the norms of good governance are becoming internalised by the organisation, they start shaping its culture as well.

Sport scholars have also explored the links between good governance, organisational culture, and effectiveness. A systematic review on the impact of governance principles on sport organisations' governance practices and performance by Parent and Hoye (2018) reveals the lack of robust empirical research on which governance principles should sport organisations adopt and implement to optimise their governance performance. This finding supports the conclusions by Cuervo-Cazurra and Aguilera (2004) and Haxhi and Van Ees (2010) that the GGC promote different forms of isomorphism. The lack of evidence for positive correlation between GGC and performance suggests that those codes have been adopted under coercive, normative, or mimetic pressure and often in the absence of knowledge about the presence of such positive correlation. Mrkonjic's (2016) analysis of nine governance codes issued by various international organisations 
reinforces the above observation. He finds that there was a lack of commonly agreed principles, and that several codes were marked by a low level of enforcement and the lack of implementation.

A rare study by Malagila et al. (2020) on corporate governance and performance of the UK premier leagues echoes the above conclusions that the size of the organisation does matter. Papadimitriou and Taylor (2000) also confirm that the size and external liaisons of the NGB's Board are key factors for the effective governance along with the interests of different stakeholders, internal processes, strategic orientation, and science support.

Chaker's (2004) survey of good governance in Europe provides some clues as to why organisational culture and governance diverge. The survey reveals principle differences in state regulation of sport in Europe where some states take an interventionist approach by providing $95 \%$ of NGB's funding (i.e. Croatia, Georgia, Lithuania), whereas others take more non-interventionist approach, as in Finland, with only $25 \%$ of sport organisations' funding coming from the state. Some states also tend to take a more centralised approach to the distribution of lottery finding than others.

The new UK Code for Sport Governance (Sport England/UK Sport 2016) provides an illuminating example for coercive isomorphism and the promotion of a new governance culture. The foreword to the Code, makes this clear: "We introduce this code, then, confident that the sports sector is well-equipped, and well positioned to use it as a tool to further nurture the growing culture of good governance we already see on a daily basis" (p. 4). The Code further stipulates that "Unlike most other Governance Codes, this is a mandatory set of requirements for those organisations seeking public funding" (p. 6). At the end of 2017, 55 of 58 (95\%) NGB were compliant with the Code. However, concerns were raised by many officials that the implementation of the Code was very time consuming, entailed greater administrative cost, its mandatory character has been a deterrent for recruiting talent to serve on Boards, and it was seen by some sports as 'one size fit all' approach and thus, a 'tick box' exercise (Walters \& Tacon 2018). The implications for state-sport organisations relationship are that in less-interventionists countries, members of the NGB will have a greater autonomy in the governance of their organisations compared to the more interventionist one.

Another comprehensive report on the status of good governance in international summer Olympic sport federations (IF) shows significant variations in their scores ranging from 84 to 187 (out of 200, ASOIF 2020). Of the six highest scoring IF, three-FIFA, International Cycling Union (UCI) and International Equestrian Federation (FEI) — are headquartered in Switzerland, the International Tennis Federation is based in London and the World Rugby is in Ireland. Only one IF, BWF (Badminton World Federation), has its headquarters in Malaysia. Four of the six IF are also in the group of five IF earning more than CHF $50 \mathrm{~m} /$ year and employing over 120 staff. Thus, the size and location of a sport organisation appear to be key factors in determining its level of good governance as it will be subjected to the influence of the prevailing culture in the country. This 
conclusion is supported by studies in the business sector (Mudashiru 2014; Smith et al. 2002), and as Peterson and Smith (1997, p. 934) elucidate "the link between nation and culture tends to occur because people prefer to interact with other people and be guided and politically governed by institutions consistent with values and beliefs with which they identify".

\section{Conclusion: On the limits and opportunities for a cultural perspective on good governance}

The analysis of the relationship between organisational culture and good governance suggests that these two concepts are mutually constructive. However, several fundamental differences between the concepts were also revealed meaning that equally, there is a parallel process of divergence as well.

First, culture is a descriptive not an evaluative concept. It either describes what an organisation has (i.e. functionalist perspective) or what is (i.e. interpretative/ metaphor perspective) (Alvesson 2002; Smircich 1983). Good governance is essentially an evaluative concept as it primary function is to evaluate the extent to which an organisation is governed well or not and to confer legitimacy over it. Second, good governance subscribes to the functionalist and humanistic interpretations of culture. According to Stocking (1966, p. 868) humanist culture is plural and progressive, and its traditional usage distinguishes between degrees of 'culture' in much the same way as we distinguish between degrees of good governance according to the score obtained. The humanist interpretation of culture became associated with the 'civilization process' with which the West has justified its attempts to conquer the world (cf. Girginov 2010), so in this regard, culture bears striking similarities with the domination of the Anglo-Saxon model of good governance. A functionalist/humanist perspective on governance fails to recognise organisations as mini societies grounded in their own ideologies, beliefs, and values, who actively interpret the reality and try to make sense of it. Finally, good governance promotes coercive, normative, and mimetic isomorphism supported by the deliberate efforts of international sport organisations, national governments, and professional associations. This isomorphism runs counter to the essence of culture which is to discriminate (Kopytoff 1986) as different sports and groups try to assert their identities by distinguishing themselves from others. The fundamental values on which culture is based represent differences that cannot be randomly added or combined in a code, they can only be reconciled through interactions and meaning construction.

The above reflections allow for drawing some implications for researchers and practitioners. The application of the culture concept to the study of good governance helps to interrogate the interplay between universal codes (i.e. etics) and the myriad of locally meaningful interpretations (i.e. emics), which may result in less abstract and more practical GGC. Practitioners will benefit from developing culturally meaningful definitions of good governance and their operationalisation based on ongoing dialogue with various constituencies. 


\section{References}

Aguilera, R \& Cuervo-Cazurra, A 2009, 'Codes of good governance', Corporate Governance: A International Review, vol. 17, no. 3, pp. 376-87. doi:10.1111/j.1467-8683.2009.00737.x

Alvesson, M 2002, Understanding Organizational Culture, Sage, London. doi:10.4135/ 9781446280072

ASOIF 2017, First Review of IF Governance: 2017 ASOIF General Assembly, ASOIF, Lausanne.

ASOIF 2020, Third Review of International Federation Governance, ASOIF, Lausanne.

Căjvăneanu, D 2011, 'A Genealogy of Government. On Governance, Transparency and Partnership in the European Union, A Dissertation Submitted in Partial Fulfilment of the Requirements for the Degree of Doctor of Philosophy School of International Studies', University of Trento, Trento.

Chaker, A 2004, Good Governance in Sport: A European Survey, Council of Europe, Strasburg.

Cuervo-Cazurra, A \& Aguilera, R 2004, 'Codes of good governance worldwide: What is the trigger?', Organization Studies, vol.25, no.3, pp. 415-443. doi:10.1177/0170840604040669.

Dennison, DR \& Mishra AK 1995. "Toward a theory of organizational culture and effectiveness”, Organization Science, vol. 6, no. 2,pp. 204-23. doi/abs/10.1287/orsc.6.2.204

European Union Expert Group 2013, "Good Governance" Deliverable 2 Principles of Good Governance in Sport, European Union, Brussels.

Feldman, SP 1986, 'Management in context: An essay on the relevance of culture to the understanding of organizational change', Journal of Management Studies, vol. 23, no. 6, pp. 587-607. https://doi.org/10.1111/j.1467-6486.1986.tb00438.x

Geeraert, A 2018. Sports Governance Observer 2018. An Assessment of Good Governance in Five International Sports Federations. Play the Game/Danish Institute for Sports Studies, Aarhus.

Girginov, V 2010, 'Culture and the study of sport management', European Sport Management Quarterly, vol. 10, no. 4, pp. 397-417. doi:10.1080/16184742.2010.502741

Girginov, V 2019, 'A cultural perspective on good governance in sport', in M Winand \& C Anagnostopoulos (eds), Research Handbook on Sport Governance, Edward Elgar, Cheltenham, pp. 89-101. doi:10.4337/9781786434821.00012

Girginov, V, Papadimitriou, D \& D'Amico, R 2006, 'Cross-cultural competence of sport managers', European Sport Management Quarterly,vol. 6, no. 1, pp. 35-66.

Haxhi, I \& Van Ees, H 2010, 'Explaining diversity in the worldwide diffusion of codes of good governance', Journal of International Business Studies, vol. 41, no. 1, pp. 710-26. doi:10.1057/jibs.2009.39

Horne, J, Thomlinson, A \& Whannel, G 1999, Understanding Sport: An introduction to the Sociological and Cultural Analysis of Sport, Spon Press, London.

Hofstede, G 1993, 'Cultural constrains in management theories', Academy of Management Executive, vol. 7, no. 1, pp. 81-90. doi:10.5465/ame.1993.9409142061

Houlihan, B \& Green, M 2009, 'Modernization and sport: The reform of Sport England and UK Sport', Public Administration, vol. 87, no. 3, pp. 678-98. doi:10.1111/j.14679299.2008.01733.x

Houlihan, B \& Groeneveld, M 2010, 'Social capital, governance and sport', in M Groeneveld, B Houlihan \& F Ohi (eds), Social Capital and Sport Governance in Europe, Routledge, Oxon, pp. 1-20. 
International Sport and Culture Association and Transparency International 2013, Grassroots Governance: Focus on Policy, People and Processes, ISCA, Rome.

Jung, T, Scott, T, Davies, HTO, Bower, P, Whalley D, McNally, R \& Mannion, R 2009, 'Instruments for exploring organizational culture: A review of the literature', Public Administration Review, vol.69, no.6,pp. 1087-96.doi:10.1111/j.1540-6210.2009.02066.x

Khan, MH 2012, 'Governance and growth: History, ideology, and methods of proof' in A Noman, K Botchwey, H Stein \& JE Stiglitz (eds), Good Growth and Governance in Africa: Rethinking Development Strategies, Oxford University Press,Oxford, pp. 51-79. doi:10.1093/acprof:oso/9780199698561.003.0002

Kjær, AM 2004, Governance, Polity Press, Cambridge.

Kopytoff, I 1986, 'The cultural biography of things: Commoditization as process', in A Appadurai (eds), The SocialLife of Things. Commodities in CulturalPerspective, Cambridge University Press, Cambridge, pp. 64-91. doi:10.1017/CBO9780511819582.004

Koskinen, K 2014, 'Institutional translation: The art of government by translation', Perspectives, vol. 22, no. 4, pp. 479-92. doi:10.1080/0907676X.2014.948887

Li, M, MacIntosh, E \& Bravo, G (eds) 2012, International Sport Management,Human Kinetics, Champaign, IL.

Lusted, J \& O'Gorman, J 2010, 'The impact of New Labour's modernisation agenda on the English grass-roots football workforce'. Managing Leisure, vol. 15, no 1-2, pp. 140-54.

Malagila, JK, Zalata, AM, Ntim, CG \& Elamer, AA 2020, 'Corporate governance and performance in sport organisations: The case of UK premier leagues', International Journal of Finance Ë Economics, vol. 26, no. 2, pp. 2517-37. doi:10.1002/ijfe.1918.

Morgan, G 1997, Images of Organization, Sage, London.

Martin, J 1992, Cultures in Organizations: Three Perspectives, Oxford University Press, New York.

Maitland, A, Hills, LA \& Rhind, DJ 2015, 'Organisational culture in sport: A systematic 13 review', Sport Management Review, vol. 18, no. 4, pp. 501-16. doi:10.1016/ j.smr.2014.11.004

Mrkonjic, M 2016, Review of Good Governance Principles and Indicators in Sport. International Centre for Sports Studies (CIES), Neuchâtel.

Mudashiru, A 2014, 'Good corporate governance and organisational performance: An empirical analysis Adebayo', International Journal of Humanities and Social Science, vol. 4, no. 7, pp. 170-78.

Niedlich, S, Kummer, B, Bauer, M, Rieckmann, M \& Bormann, I 2019, 'Cultures of sustainability governance in higher education institutions: A multi-case study of dimensions and implications', Higher Education Quarterly, vol. 74, no. 4, pp. 373-90. doi: 10.1111/hequ.12237

Numerato, D 2010, 'Czech sport governance cultures and a plurality of social capitals: Politicking zone, movement and community', in M Groeneveld, B Houlihan \& F Ohl (eds), Social Capital and Sport Governance in Europe, Routledge, New York, pp. 41-62.

Offe, K 2009, 'Governance: An “empty signifier"?', Constellations, vol. 16, no. 4, pp. 550-62. doi:10.1111/j.1467-8675.2009.00570.x

Papadimitriou, D \& Taylor, P 2000, 'Organisational effectiveness of Hellenic national sports organisations: A multiple constituency approach', Sport Management Review, vol. 3, no. 1, pp. 23-46.

Parent, MM \& Hoye, R 2018, 'The impact of governance principles on sport organisations' governance practices and performance: A systematic review', Cogent Social Sciences, vol. 4, no. 1. doi:10.1080/23311886.2018.1503578 
Peterson, M \& Smith, P 1997, 'Does national culture or ambient temperature explain cross-national differences in role stress? No sweat!', Academy of Management Journal, vol. 40, no. 4, pp. 930-46.

Rhodes, RAW 1996. The new governance: governing without government. Political Studies, vol. 44, no. 4, pp.652-67. doi:10.1111/j.1467-9248.1996.tb01747.x

Smircich, L 1983, 'Concepts of culture and organizational analysis', Administrative Science Quarterly, vol. 28, no. 3, pp. 339-58. doi:10.2307/2392246

Seippel, $\varnothing$, Dallen, H, Sandvik, M \& Solstad, G 2018, 'From political sports to sports politics: On political mobilization of sports issues', International Journal of Sport Policy and Politics, vol. 10, no. 4, pp. 669-86.

Shilbury, D, Ferkins L \& Smythe, L (2013), 'Sport governance encounters: Insights from lived experiences', Sport Management Review, vol. 16, no. 3, pp. 349-63. doi:10.1016/ j.smr.2012.12.001.

Smith, P, Peterson, M \& Schwartz, S 2002, 'Cultural values, sources of guidance, and their relevance to managerial behaviour', Journal of Cross-Cultural Psychology, vol. 33, no. 2, pp. 188-208.

Sotiriadou, P \& De Haan, D 2019, 'Women and leadership: advancing gender equity policies in sport leadership through sport governance', International Journal of Sport Policy and Politics, vol. 11, no. 3, pp. 365-83. doi:10.1080/19406940.2019.1577902

Spencer-Oatey, H 2012, 'What is culture? A compilation of quotations', GlobalPAD Core Concepts, GlobalPAD Open House.

Sport England/UK Sport 2016, A Code for Sports Governance, Sport England, London.

Stocking, G 1966, 'Franz Boas and the culture concept in historical perspective', American Anthropologist, vol. 68, no. 1, pp. 867-82.

Treib, O, Bähr, H \& Falkner, G 2007, 'Modes of governance: Towards a conceptual clarification', Journal of European Public Policy, vol. 14, no. 1, pp. 1-20. doi:10.1080/ 19406940.2019.1577902

United Nations 2016, The Sustainable Development Goals Report 2016.

Walters, G \& Tacon, R 2018, 'The 'codification' of governance in the non-profit sport sector in the UK', European Sport Management Quarterly, vol. 18, no. 4, pp. 482-500. doi:10.1080/16184742.2017.1418405

Wiliams, R 1989, 'Culture is ordinary', in A Gray \& J McGuigan (eds), Studying Culture: An Introductory Reader, Edward Arnold, London, pp. 5-14. 